\title{
Candida albicans Virulence Factors and Pathogenicity for Endodontic Infections
}

\author{
Yeon-Jee Yoo ${ }^{1,+}{ }^{\text {, A Reum Kim }}{ }^{2,+}{ }^{\circledR}$, Hiran Perinpanayagam ${ }^{3}{ }^{\circledR}$, Seung Hyun Han ${ }^{2}$ and \\ Kee-Yeon Kum 4,5,*iD \\ 1 Department of Comprehensive Treatment Center, Seoul National University Dental Hospital, \\ Seoul 03080, Korea; dusw132@snu.ac.kr \\ 2 Department of Oral Microbiology and Immunology, School of Dentistry, Dental Research Institute and BK21 \\ Plus Program, Seoul National University, Seoul 08826, Korea; kimareum@snu.ac.kr (A.R.K.); \\ shhan-mi@snu.ac.kr (S.H.H.) \\ 3 Schulich School of Medicine \& Dentistry, University of Western Ontario, London, ON N6A 5C1, Canada; \\ hperinpa@uwo.ca \\ 4 Department of Conservative Dentistry, Dental Research Institute and BK21 Plus Program, \\ Seoul National University Dental Hospital, Seoul National University School of Dentistry, \\ Seoul 03080, Korea \\ 5 National Dental Care Center for Persons with Special Needs, Seoul National University Dental Hospital for \\ Persons with Special Needs, Seoul 03080, Korea \\ * Correspondence: kum6139@snu.ac.kr; Tel.: +82-2-2072-2656 \\ + These authors contributed equally to this article.
}

Received: 14 July 2020; Accepted: 19 August 2020; Published: 26 August 2020

\begin{abstract}
Candida albicans (C. albicans) is the fungus most frequently isolated from endodontic root canal infections. Although recognized by dental pulp and periradicular tissue cells that elicit immune responses, it eludes host defenses and elicits cell death. Then, C. albicans binds tooth dentin, forms biofilms, and invades dentinal tubules to resist intracanal disinfectants and endodontic treatments. Insensitive to most common medicaments, it survives sequestered within biofilms and intratubular dentin. Thus, C. albicans has been associated with cases of persistent or refractory root canal infections. Its treatment strategies may require alternative intracanal irrigants, intracanal medicaments such as chlorhexidine gel or human beta defensin-3 (HBD3), Ca-Si-based obturating materials, and microsurgical procedures.
\end{abstract}

Keywords: biofilm; Candida albicans; endodontics; intraradicular eradication; pathogenicity; persistent infection; virulence factors

\section{Candida Infection in Endodontics}

Microbial infections of the dental pulp and root canals can lead to an inflammatory disease in the periradicular tissues, known as apical periodontitis. These endodontic infections develop through pulp exposures due to dental caries, traumatic tooth fractures, or cracks [1]. Fungi are frequently involved and have been isolated from approximately $3-18 \%$ of infected root canals [2], with a predominance of the Candida species [2,3]. A systematic review and meta-analysis showed that Candida albicans is the fungus most commonly isolated from infected root canals, followed by Candida tropicalis, Candida kefyr, Candida parapsilosis, Candida glabrata, Candida krusei, Candida dubliniensis, Candida guilliermondii, and Candida etchellsii [3].

C. albicans binds to both biotic and abiotic surfaces, such as dental prostheses and tooth dentin. It is dentinophilic and colonize the dentin walls of root canals, penetrating the dentinal tubules and forming biofilms (Figure 1). The round C. albicans cells attach to dentin surfaces over 60-90 $\min$ [4-6], and then 
proliferate to form a basal layer of biofilm that matures in $24 \mathrm{~h}$. Mature biofilms contain multiple layers of polymorphic cells consisting of hyphal, pseudohyphal, and yeast forms that are embedded within extracellular matrices, creating thick and physiochemically hard structures. Then, round yeast cells from mature biofilms disperse to infect distant sites. C. albicans within biofilms is 10-100 fold more resistant to host immune responses and antifungal treatment, because the cell growth and metabolism are slowed and protected by extracellular polymeric substances (EPS) and protective factors [5,6]. Thus, C. albicans in biofilms is more difficult to remove than planktonic cells, and it is commonly found in persistent/refractory endodontic infections that do not respond to root canal treatment.

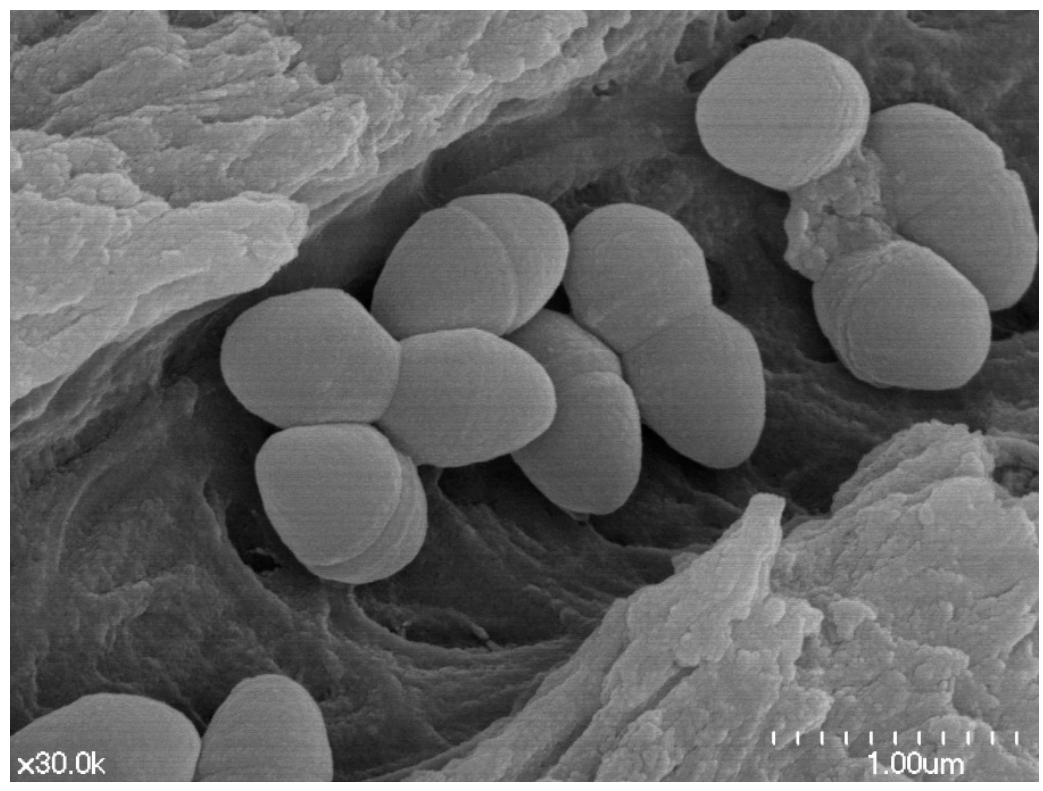

Figure 1. Scanning electron microscopic view of Candida albicans cells penetration into dentinal tubules after 3-weeks infection in human root dentin block. Blastospores and cells showing germ tube formation $(30,000 \times)$.

C. albicans is dimorphic and switches from round yeast cells to hyphal forms that invade and induce host immune responses [7]. Yeasts bind oral epithelial cells and rapidly switch to hyphae [8,9] that invade via two mechanisms [7,9]. Adhesins on the cell wall of hyphae induce endocytosis in the host cells $[10,11]$. These agglutinin-like sequence (ALS) proteins on hyphae promote host cell adherence and endocytosis [12]. For example, ALS3 regulated by Bcr1 is a $\mathrm{C}_{2} \mathrm{H}_{2}$ zinc finger protein of C. albicans that attaches to host receptors including $\mathrm{N}$ - and E-cadherins, and induces endocytosis in the host cells $[11,13,14]$. Additionally, hyphae can actively penetrate the plasma membrane of epithelial cells [7]. Both mechanisms of invasion occur in oral epithelium, whereas only active penetration occurs in intestinal epithelial cells.

The adherence to surfaces is mediated through a thick cell wall, with a core structure consisting of chitin, $\beta$-(1,3)-glucan, and $\beta-(1,6)$-glucan (Figure 2$). \quad \beta$-(1,3)-glucan is covalently linked to other components forming a three-dimensional network $[15,16]$. Adjacent to this core complex lies the membrane as an inner layer with components that can be exposed to host cells during yeast budding [17]. The other end is the outer layer consisting of mannan and various cell wall proteins [16], which are linked to inner layer components primarily though glycosylphosphatidylinositol to $\beta$ - $(1,3)$-glucan or $\beta$ - $(1,6)$-glucan to chitin. The cell wall proteins are highly glycosylated with mannan, with $O$-linked mannan through their Ser/Thr-rich domains, and $N$-linked mannan with a conserved (Mannose $)_{8}(\mathrm{~N} \text {-acetylglucosamine })_{2}$ structure as a core attached to diverse outer chains. The outer chain consists of an $\alpha-(1,6)$-mannose backbone, and $\alpha-(1,2)-\beta-(1,2)-$ and $\alpha-(1,3)$-linked mannose and 
phosphomannose as side chains $[15,16,18]$. The exposure of these components can induce host immune responses.

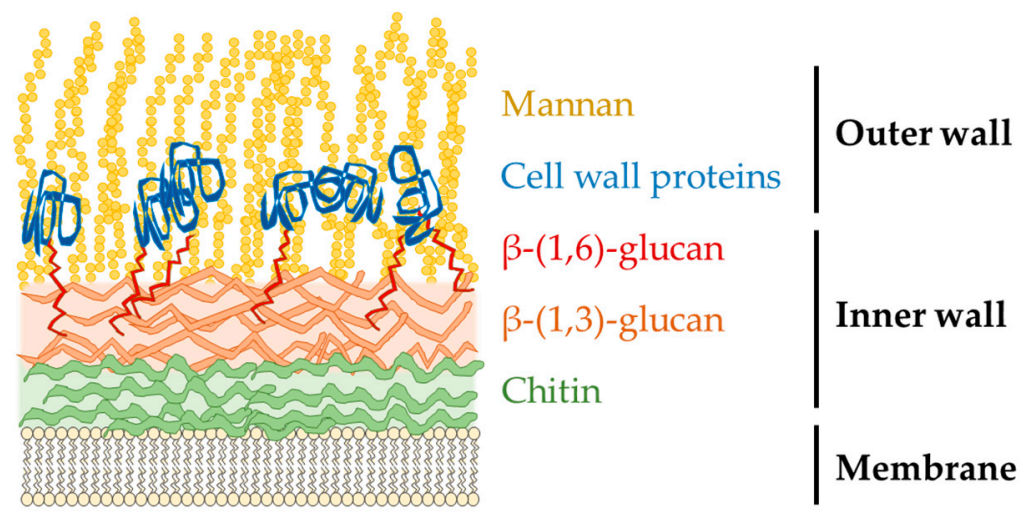

Figure 2. Candida albicans cell wall structures in yeast and hyphal forms have similar composition. However, chitin in the inner wall of hyphae is at least three times thicker than in yeast, and the amount of mannose in the mannan of yeast is higher than in that of hyphae $[19,20]$.

\section{Virulence Factors and the Pathogenetic Mechanism in Pulp and Periapical Lesions}

As root canals are colonized and invaded by C. albicans [3,21], it encounters host cells and elicits an immune response from periapical tissues. Histopathologically, chronic apical periodontitis lesions involve periapical granulomas and sometimes apical cysts. Granulomas are chronic inflammatory tissues heavily infiltrated with neutrophils, macrophages, T- and B-lymphocytes, mast cells, osteoclasts, osteoblasts, fibroblasts, and epithelial cells, and they are enclosed by a fibrous capsule [22-26]. A periapical cyst consists of an epithelial-lined cavity within the granuloma [22-24].

\subsection{Recognition of C. albicans by Immune Cells}

Cell wall components such as chitin, glucan, or mannans, DNA, RNA, and quorum-sensing molecules in C. albicans, are involved in recognition by monocytes and macrophages (Table 1 ). These involve host pattern recognition receptors (PRRs), such as Toll-like receptors (TLR), c-type lectin receptor (CLR), nucleotide-binding oligomerization domain-like receptors (NLR), and retinoic-acid inducible gene-1-like receptors (RLR) [27].

Phospholipomannan on $C$. albicans is recognized by TLR2 on macrophages that activate nuclear factor- $\kappa B(N F-\kappa B)$ and produce tumor necrosis factor (TNF)- $\alpha$. [28]. Mannan purified from C. albicans induced TNF and Interleukin 6 (IL-6) in human mononuclear cells and murine macrophages, whereas mannosylation-defective mutants stimulated significantly less of both cytokines. $O$ - and $N$-linked mannosyl residues induced cytokines via TLR4 and mannose receptors, respectively [29]. Mannan from C. albicans, and not Saccharomyces cerevisiae, induced IL-17 in human peripheral blood mononuclear cells (PBMCs), which was dependent on macrophage mannose receptors [30]. Mannose receptor-mediated IL-17 release is enhanced by the TLR2/dectin-1 pathway. Both TLR2 and dectin- 1 receptors recognized $\beta$-glucan in the cell wall of $C$. albicans and induced cytokine production [29]. Thus, mannan and $\beta$-glucan may together induce more severe inflammatory responses.

$\beta$-glucans bind to dectin-1, an extracellular CLR, which stimulates macrophages and dendritic cells to phagocytose $C$. albicans. Dectin-1 recognizes $C$. albicans in their yeast form, but not as hyphae or pseudohyphae. $\beta$-glucans are unexposed during hyphal or pseudohyphal growth, but are exposed during yeast budding and cell division to trigger phagocytosis and the production of reactive oxygen [17]. This non-exposure of $\beta$-glucans in hyphae may be a strategy for $C$. albicans to evade phagocytosis by macrophages. Other CLRs that recognize C. albicans include Mincle, which has a key role in the immune response against C. albicans [31]. C. albicans induced TNF- $\alpha$ production in macrophages, which was reduced in Mincle-deficient mice that were more susceptible to the infection. 
On the other hand, a soluble CLR, mannan-binding lectin (MBL), inhibited C. albicans-induced proinflammatory cytokines and chemokine production in human macrophages by inhibiting the C. albicans-mediated TLR2 and TLR4 expression and blocking TLR2 and TLR4 activation [32]. However, multiple CLRs, including Dectin-1, Dectin-2, and Mincle, collaborate to remove C. albicans during systemic infections [33]. The protective effect of multiple CLRs over single receptors was potently enhanced in monocytes, but not in neutrophils, which have lower levels of CLRs. Indeed, multiple CLR-deficient mice failed to control C. albicans growth due to an inadequate inflammatory response from monocytes, and induced hyper-inflammatory responses leading to organ failure. Thus, multiple CLRs cooperate in removing $C$. albicans and preserving organ function during infection.

C. albicans triggered pyroptosis of macrophages by caspase-1, an apoptosis-associated speck-like protein containing a caspase recruitment domain (ASC), and the NLR family pyrin domain, containing 3 (NLRP3) inflammasome. Pyroptosis was dependent on the transcription factor sterol uptake control protein 2 (UPC2) in C. albicans, which has a role in regulating ergosterol production and resistance to antifungal agents [34]. C. albicans hyphae formation triggered the NLRP3 inflammasome in macrophages [35], especially hyphae-derived candidalysin-induced NLRP3 inflammasome-mediated pyroptosis and the IL-1 $\beta$ secretion for macrophages and mononuclear phagocytes [36,37]. C. albicans secreted aspartic proteases 2 and 6, activated the NLRP3 inflammasome, and induced IL-1 $\beta$, TNF- $\alpha$, and IL- 6 production in monocytes, macrophages, and dendritic cells [38]. $\beta$-glucans also triggered NLRP3 inflammasome-dependent IL-1 $\beta$ secretion in immune cells, including dendritic cells, through complement receptor 3 and dectin-1 signaling [39]. NLRP3-deficiency affected the control of C. albicans infections, induction of $\mathrm{T}$ helper (Th) 17 cell responses, and production of proinflammatory cytokines in macrophages and dendritic cells, while NLRP10-deficiency reduced Th1 and Th17 responses without affecting the production of innate proinflammatory cytokines [40]. Thus, NLRP3 may have a key role in the innate immune responses against $C$. albicans, whereas NLRP10 is important for anti-fungal adaptive immunity.

C. albicans can inhibit nitric oxide production in human macrophages by enhancing host arginase activity [41]. Purified chitin, or the increased exposure of chitin, induced arginase activity in host cells, whereas an arginase inhibitor or chitinase inhibitor recovered nitric oxide production and the capacity for killing C. albicans. However, C. albicans affects macrophage activation and modulates arginase metabolism to avoid death.

C. albicans is also internalized by dendritic cells, which are specialized antigen-presenting cells found in the dental pulp and periapical lesions $[42,43]$. The yeast form enters via mannose receptors that induce proinflammatory cytokines and are killed after internalization. However, hyphal forms that enter through complement receptor 3 are found in the cytoplasm of dendritic cells $[43,44]$.

Mast cells are long-lived immune cells found in the pulp and periapical lesions that produce TNF- $\alpha$, IL-6, IL-13, and IL-4 in response to C. albicans [45]. They engulf C. albicans hyphae via $\alpha$-tubulin cytoskeletal rearrangement and the accumulation of the late phase marker lysosomal-associated membrane protein-1 (LAMP1) vesicles at the phagocytic synapses [45]. Mast cells infected by C. albicans enhanced chemotaxis and the movement of macrophages to the infection site, whereas uninfected mast cells inhibited the macrophage phagocytosis of $C$. albicans. Thus, mast cells inhibited C. albicans growth and regulated macrophage responses.

IL-17 was released by T cell receptor (TCR) $\alpha \beta^{+}$cells when they were stimulated with C. albicans. A C. albicans mutant that was unable to form hyphae was impaired in inducing TCR $\alpha \beta^{+}$cell proliferation and IL-17a expression. Also, candidalysin-deficient $C$. albicans lost the ability to induce IL-17a production and innate TCR $\alpha \beta^{+}$cell proliferation. Thus, candidalysin in C. albicans hyphae may have a key role in inducing the inflammatory response in lymphocytes [46]. 
Table 1. Immune cell recognition and response to Candida albicans.

\begin{tabular}{|c|c|c|c|c|c|}
\hline Host Cell & Component of $C$. albicans & Receptor or Mechanisms & Increase & Decrease & Ref \\
\hline macrophages & phospholipomannan & TLR2 & TNF-a & 1 & [28] \\
\hline human mononuclear cell, murine & purified mannan & / & TNF, IL-6 & / & [29] \\
\hline human mononuclear cells & O-linked mannosyl residues & TLR4 & l & 1 & [29] \\
\hline human mononuclear cells & $\mathrm{N}$-linked mannosyl residues & mannose receptor & 1 & i & [29] \\
\hline human peripheral blood mononuclear cells & mannan & mannose receptor & IL-17 & i & [30] \\
\hline human peripheral blood mononuclear cells & mannan, $\beta$-glucan & TLR2/denctin-1 & mannose receptor-induced IL-17 & i & [30] \\
\hline human mononuclear cells & $\beta$-glucan & TLR2/denctin-1 & induced cytokine production & 1 & [29] \\
\hline macrophages & $\beta$-glucan & dectin-1 & reactive oxygen, phagocytosis & i & [17] \\
\hline macrophages & 1 & mincle & TNF- $\alpha$ & 1 & [31] \\
\hline human macrophages & 1 & mannan-binding lectin & I & $\begin{array}{l}\text { C. albicans-induced } \\
\text { proinflammatory cytokines }\end{array}$ & [32] \\
\hline monocyte & 1 & multiple CLR (Dectin-1, Dectin-2 and Mincle) & 1 & $\begin{array}{l}\text { Proinflammatory y ytokines } \\
\text { remove fungus }\end{array}$ & [33] \\
\hline macrophage & transcription factor UPC2 & caspase-1, ASC, and NLRP3 Inflammasome & pyroptosis & $/ /$ & [34] \\
\hline macrophage, monocuclear phagocytes & hyphae, hyphae-derived toxin candidalysin & NLRP3 Inflammasome & pyroptosis and IL- $1 \beta$ secretion & i & [35-37] \\
\hline monocyte, macrophage, dendritic cells & Secreted aspartic proteases 2 and 6 & NLRP3 inflammasome & induced IL- $1 \beta$, TNF- $\alpha$, and IL- 6 production & 1 & [38] \\
\hline dendritic cells & $\beta$-glucans & $\begin{array}{l}\text { caspase-8 and NLRP3 inflammasome, } \\
\text {. }\end{array}$ & IL- $1 \beta$ secretion & i & [39] \\
\hline macrophage and dendritic cell & 1 & NLRP10 & Th1 and Th17 responses & l & [40] \\
\hline human macrophages & purified chitin or increased exposure of & enhancement of host arginase activity & 1 & nitric oxide production & [41] \\
\hline dendritic cells & $\begin{array}{l}\text { morphology of C. albicans and type of } \\
\text { receptor mediated the entry into cells }\end{array}$ & mannose receptor/CR3 & production of proinflammatory cytokines & / & [42] \\
\hline mast cell & receptor maratea the entry into cens & $\begin{array}{l}\alpha \text {-tubulin cytoskeleton rearrangement and } \\
\text { accumulation LAMP1 }{ }^{+} \text {vesicles }\end{array}$ & $\begin{array}{l}\text { production of TNF- } \alpha, \text { IL-6, IL-13, and IL-4, } \\
\text { phagocytosis of hyphae form of C. albicans, enhanced } \\
\text { chemotaxis and movement of macrophages. }\end{array}$ & I & [45] \\
\hline $\mathrm{TCR} \alpha \beta^{+}$cells & hyphae, candidalysin & 1 & IL- $17^{+}$TCR $\alpha \beta^{+}$cell proliferation & / & [46] \\
\hline
\end{tabular}




\subsection{Recognition of C. albicans by Non-Immune Cells}

There are also non-immune cells in pulp and periapical lesions, including pulp cells, periodontal ligament (PDL) cells, fibroblasts, and epithelial cells, that respond to C. albicans (Table 2). They respond through other receptors, including specialized PRRs such as TLR, CLR, NLR, and RLR.

Oral epithelial cells have PRRs that mediate immune responses. Ephrin type A receptor 2 (EphA2) on these cells bound $\beta$-glucans on C. albicans, which induced proinflammatory and antifungal responses via the activation of the signal transducer and the activator of transcription 3 (Stat3), and via mitogen-activated protein kinase (MAPK) signaling [47]. EphA2-deficient mice demonstrated reduced inflammatory responses and IL-17 signaling, resulting in severe disease. Thus, EphA2 PRR on oral epithelial cells is a key to sensing $C$. albicans and inducing an immune response.

The oral epithelium responded to $\beta$-glucan of $C$. albicans with elevated heme oxygenase- 1 (HO-1) expression via the generation of intracellular reactive oxygen species, p38 MAPK phosphorylation, and nuclear factor erythroid 2-related factor 2 (Nrf2) translocation into the nuclei [48]. HO-1 overexpression led to reduced cytotoxicity and injury caused by oxidative stress [49]. Thus, the oral epithelial cell expression of HO-1 in response to $C$. albicans $\beta$-glucan may be an important protective mechanism. The Als3p and Ssa1p genes of $C$. albicans also triggered local immune responses by inducing the production of cytokines and chemokines in oral epithelial cells [50]. C. albicans up-regulated the secretion of galectin-3 on human gingival epithelial cells and fibroblasts via cytoskeletal changes, protease activity, or phosphoinositide 3-kinases (PI3K) signaling [51].

The oral epithelial cell responses to C. albicans were different from those of vaginal epithelial cells [50]. Oral epithelial cells infected by C. albicans are efficient at releasing cytokines such as IL- $1 \alpha$ or IL- $1 \beta$, and chemokines such as IL- 8 or MIP-3 $\alpha$, rather than directly killing C. albicans. Conversely, C.albicans can kill oral epithelial cells. They interact with oral epithelial cells, invade them, and rapidly activate caspase-dependent apoptosis, which results in cell death [52]. However, C. albicans-infected oral epithelial cells can enhance C. albicans hyphal damage by neutrophils [53]. The supernatant of C. albicans-infected oral epithelial cells stimulated neutrophils to suppress the metabolic activity of hyphal C. albicans. This was partially inhibited by anti-IL-1 $\alpha$ and IL-1 receptor neutralizing antibodies. Thus, C. albicans-infected oral epithelial cells can stimulate neutrophil anti-hyphal activity though cytokines.

C. albicans can regulate the production of chemokines, such as fractalkine/C- $\mathrm{X}_{3}-\mathrm{C}$ Motif Chemokine Ligand 1 (CX3CL1), which act as chemoattractants and adhesion molecules in fibroblasts [54]. C. albicans increased the mRNA levels of several chemokines except CX3CL1 in keratinocytes, and they induced CX3CL1 expression in human oral fibroblasts. CX3CL1 chemokines showed antifungal effects against C. albicans. Thus, CX3CL1 from oral fibroblasts may play a key role in the oral immune response to C. albicans infection.

PDL cells are also involved in immune responses when they encounter pathogenic microorganisms. C. albicans in biofilms persistently stimulated PDL cells expression of IL- 6 and TNF- $\alpha$, or IL- $1 \beta$ and the receptor activator of nuclear factor kappa-B ligand (RANKL), which are involved in bone resorption [55]. Additionally, C. albicans reduced PDL cells expression of IL-10, which is an anti-inflammatory cytokine that inhibits the expression of proinflammatory cytokines.

Dental pulp cells are involved in the repair and regeneration of pulpal tissues and dentin. However, they can be killed by C. albicans [56]. C. albicans hyphae invade pulp cells and secrete degradative proteases that cause cell damage. C. albicans enhanced pulp cell expression of the C-type lectin domain containing 7A (CLEC7A), TLR2, and TLR4, which act as fungus-associated receptors and produce proinflammatory cytokines such as interferon (IFN)- $\alpha$. C. albicans infection also increased the production of FOXO3a, which is a key transcription factor involved in the immune response. Thus, dental pulp cells may influence the production of proinflammatory cytokines against C. albicans. 
Table 2. Recognition of Candida albicans by non-immune cells.

\begin{tabular}{|c|c|c|c|c|c|}
\hline Host Cell & $\begin{array}{l}\text { Component of } \\
\text { C. albicans }\end{array}$ & Receptor or Mechanisms & Increase & Decrease & Ref \\
\hline oral epithelium & $\beta$-glucans -containing particles & reactive oxygen species (ROS)/p38 MAPK/Nrf2 & heme oxygenase-1 (HO-1) expression & 1 & [48] \\
\hline oral epithelial cells & Als3p and Ssa1p gene & & production of cytokine and chemokine & i & [50] \\
\hline human gingival epithelial cell, fibroblasts & 1 & cytoskeletal changes, protease activity, or PI3K signaling & secretion of galectin-3 & i & [51] \\
\hline oral epithelial cells & I & 1 & $\begin{array}{l}\text { release of cytokines such as IL- } 1 \alpha \text { or IL- }-1 \beta \text { and chemokines such as } \\
\text { IL- } 8 \text { or Macrophage Inflammatory Protein (MIP)-3 } \alpha\end{array}$ & I & [50] \\
\hline oral epithelial cells & 1 & 1 & caspase-dependent apoptosis & I & [52] \\
\hline oral epithelial cells & 1 & neutrophils, IL-1 signaling & C. albicans hyphae damage & 1 & [53] \\
\hline oral fibroblasts & i & 1 & fractalkine/CX3CL1 (CX3CL1) & i & [54] \\
\hline keratinocyte & I & I & increased mRNA levels of several chemokines excepting CX3CL1 & & [54] \\
\hline periodontal ligament $(\mathrm{PDL})$ cell & l & l & $\begin{array}{l}\text { induced expression of IL-6 and TNF- } \alpha \text {, or IL-1 } \beta \text {, RANKL, IL-23 } \\
\text { p19, and IL-17R }\end{array}$ & $\begin{array}{l}\text { reduced } \\
\text { IL-10 expression }\end{array}$ & [55] \\
\hline dental pulp cells & Hyphal & 1 & cell damage, expression of CLEC7A, TLR2, and TLR4, IFN- $\alpha$ & IL-10 expression & [56] \\
\hline
\end{tabular}


All of these cells may have other receptors involved in recognizing fungi. Additionally, other cell types such as odontoblasts may interact and respond to C. albicans and have a role in the immune response to $C$. albicans infection. Therefore, further studies are needed to understand the complex immune response against $C$. albicans in pulp and periapical tissues.

\subsection{Myeloid Cells Affected by C. albicans Infection}

In bone marrow, myeloid cells that originate from hematopoietic stem cells give rise to osteoclasts, macrophages, granulocytes, and dendritic cells. Siglec- 15 is a member of the glycan-recognition proteins that are primarily expressed on myeloid cells. Siglec-15 is a risk allele for recurrent vulvovaginal infection by C. albicans [57] (Table 3). Indeed, PBMCs from donors with the Siglec-15 allele increased production of $\mathrm{T}$ cell cytokines such as IL-17, IL-22, and interferon- $\gamma$ by $C$. albicans more than those of donors without the risk allele. C. albicans increased Siglec-15 mRNA expression in human blood myeloid cells and epithelial cells, and directly bound Siglec-15. Osteoclast differentiation from the osteoclast precursor was reduced by using anti-Siglec-15 antibodies. Sialylated ligands induced osteoclast differentiation by the recognition of Siglec- 15 . Thus, C. albicans recognition by Siglec-15 might participate in osteoclast differentiation and fusion.

C. albicans can induce IL-23 production in monocytes, macrophages, dendritic cells, and neutrophils [58]. IL-23 was important for protection against $C$. albicans infection in a mouse model in which IL-23-deficient mice were more susceptible to C. albicans infection. IL-23 protected myeloid cells from apoptosis and promoted host defenses against systemic candidiasis [59]. However, IL-23 is associated with osteoclast differentiation in mouse macrophages and may thereby affect bone resorption during C. albicans infection.

Conversely, osteoclastogenesis was reported to be inhibited by dectin-1 signaling. In osteoclast precursors, the activation of dectin- 1 inhibited RANKL-mediated osteoclast differentiation via the inhibition of the nuclear factor of activated T cells 1 (NFATc1), dendritic cell-specific transmembrane protein (DC-STAMP), tartrate resistant acid phosphatase (TRAP), and cathepsin $\mathrm{K}$ induced by IL-33 [60]. Additionally, Dectin-1 activation inhibited osteoclast-mediated bone resorption. C. albicans $\beta-1-3$-glucans recognition by dectin- 1 may regulate osteoclastogenesis. The recognition of C.albicans-derived $\beta$-glucan by dectin-1 stimulated nociceptors to induce the production of calcitonin gene-related peptides (CGRP) [61]. The CGRP inhibited $\beta$-glucan-induced inflammation and multinucleation of osteoclasts via the inhibition of NF- $\mathrm{kB}$ p65 and the inhibition of actin polymerization, respectively. Thus, Dectin-1 signaling by $\beta$-glucan may regulate bone destruction via the induction of CGRP. Experimental osteoarthritis induced by C. albicans in rats showed irregular new bone formation and resorptions, leading to severe deformation of the joint bones [62,63]. However, further study is needed to determine the effects of $C$. albicans on oral bone turnover in periapical lesions. 
Table 3. Myeloid cells affected by Candida albicans infection.

\begin{tabular}{|c|c|c|c|c|c|}
\hline Host & Component of C. albicans & Receptor or Mechanisms & Increase & Decrease & Ref \\
\hline human myeloid cells, epithelial cells & 1 & I & $\begin{array}{l}\text { Siglec-15 messenger RNA (mRNA) expression } \\
\text { (associated with osteoclast differentiation on } \\
\text { osteoclast precursor) }\end{array}$ & I & [57] \\
\hline monocytes, macrophages, dendritic cells, neutrophils & I & 1 & $\begin{array}{l}\text { IL-23 (associated with osteoclast differentiation in } \\
\text { mouse macrophage) }\end{array}$ & I & {$[58,59]$} \\
\hline osteoclast precursor & I & $\begin{array}{l}\text { dectin-1 signaling ( } \beta-1-3 \text {-glucans of } C \text {. } \\
\text { albicans are ligands of Dectin-1), IL-33 }\end{array}$ & RANKL-mediated osteoclast differentiation & / & [60] \\
\hline mice & C. albicans-derived $\beta$-glucan & dectin-1, nociceptors & the production of calcitonin gene-related peptides & $\begin{array}{l}\text { inhibit osteoporosis and osteomyelitis } \\
\text { in response to } \beta \text {-glucan }\end{array}$ & [61] \\
\hline rat & I & I & $\begin{array}{l}\text { irregular new bone formation and resorptions, severe } \\
\text { deformation of joint bones }\end{array}$ & - & {$[62,63]$} \\
\hline
\end{tabular}




\section{Treatment Options for Endodontic C. albicans Infection}

\subsection{Intraradicular Eradication}

\subsubsection{Mechanical Instrumentation}

Most intracanal pathogens could be removed during the root canal treatment procedure, including pulp extirpation, root canal enlargement and preparation, and intracanal disinfection techniques. However, C. albicans biofilm and the smear layer on root canal walls resist and survive treatment. Although the outer layer of microbial biofilm is directly affected, the extracellular matrix structure prevents treatment procedures from affecting deeper layers of viable microorganisms. Also, microbes remain sequestered within complex root canal spaces and inside dentinal tubules as endodontic instruments cannot reach all intracanal surfaces. Such intratubular microorganisms are the primary cause of microbial resistance to treatment, and post-treatment recurrence of apical periodontitis.

\subsubsection{Chemical Irrigants}

\section{Sodium Hypochlorite}

The most widely used endodontic irrigant is sodium hypochlorite $(\mathrm{NaOCl})$, which has broad spectrum antimicrobial activity and necrotic tissue dissolving properties. Its antimicrobial actions are through free chlorine release, which is $\mathrm{pH}$-dependent and oxidizes amino acid sulfhydryl groups [64] to the di-sulfide form (S-S), causing protein breakdown [65]. Fungicidal actions involve the denaturation of proteins and the inhibition of enzymatic reactions, which reduce cell attachment and function [66]. However, these cytotoxic properties and the tissue dissolving capacity limit $\mathrm{NaOCl}$ application to short-term intracanal use.

\section{Chlorhexidine Digluconate}

Another commonly used endodontic irrigant is chlorhexidine digluconate (CHX), which consists of cationic molecules that bind dentin surfaces to provide prolonged resistance to microbial colonization (substantivity) and broad-spectrum antimicrobial activity [67]. Cationic CHX molecules interact with negatively-charged membrane phospholipids to enter and permeabilize microbial cells [68]. CHX altered cell walls and nucleoprotein coagulation in microbes, including C. albicans [69,70], and CHX was reported to be more effective against $C$. albicans compared with calcium hydroxide [71]. Additionally, CHX binds to hydroxyapatite to reduce microbial colonization on dentin surfaces, exerting substantive activity [67]. CHX showed superior antifungal activity compared with calcium hydroxide up to a $400 \mu \mathrm{m}$ depth of dentinal tubules in a human dentin block model [69]. However, dentin components (hydroxyapatite, dentin matrix, and type I collagen), microbial cells, and inflammatory exudates within infected root canals may potentially negate CHX's effects [72]. Other limitations include an incapacity to disrupt biofilms [70], remove smear layers [69], or dissolve tissues [73]. Therefore, CHX must be accompanied by other irrigants or medicaments and endodontic instrumentation. Unfortunately, $\mathrm{CHX}$ used in conjunction with $\mathrm{NaOCl}$ risks the formation of para-chloroaniline, which is a toxic aromatic amine that may cause cyanosis.

\section{Alexidine Digluconate}

Alexidine digluconate $(\mathrm{AXD})$ is an anticancer drug that targets a mitochondrial tyrosine phosphatase (PTPMT1) and causes mitochondrial apoptosis [64]. AXD inhibited planktonic growth and biofilm formation of diverse fungi and showed fungicidal effects [74]. ALX demonstrated longer antimicrobial substantivity than CHX [75], and there were no precipitates or toxic byproducts when combined with $\mathrm{NaOCl}$ [76]. Thus, ALX has recently been in the spotlight as a potential antibiofilm and antifungal agent for diverse fungal infections and for applications in endodontics. 


\section{Ethylene Diamine Tetraacetic Acid}

In endodontics, ethylene diamine tetraacetic acid (EDTA) is not used as an antimicrobial, but to remove the smear layer from root canal walls. This exposes the dentin surface and dentinal tubule orifices and increases the antimicrobial effects of other agents [77]. The antifungal properties of EDTA were first studied by Sen et al. [78], and there are two mechanisms for its antifungal activity in preventing colonization and inhibiting growth. First, EDTA chelates calcium ions $\left(\mathrm{Ca}^{2+}\right)$ and inhibits C. albicans binding to proteins, which interferes with adherence and colonization. Secondly, EDTA can remove $\mathrm{Ca}^{2+}$ from cell walls to make them collapse and inhibit enzyme reactions [79] and other divalent ions $\left(\mathrm{Mg}^{2+}, \mathrm{Mn}^{2+}\right.$ and $\left.\mathrm{Zn}^{2+}\right)$ to prevent the growth and morphogenesis of $C$. albicans [80-82]. Therefore, copious irrigation with EDTA during root canal disinfection is particularly important in persistent cases or for medically compromised patients who are susceptible to oral candidiasis.

\subsubsection{Intracanal Medicaments}

\section{Calcium Hydroxide}

Calcium hydroxide is the most widely used intracanal medicament in endodontics. The hydroxyl ions released from calcium hydroxide react intensively with several biomolecules. The reaction is nonspecific and these highly oxidant free radicals gather at their sites of generation. Hydroxyl ions damage bacterial cytoplasmic membranes, denature proteins, and damage DNA, which is fatal for bacterial cells. The hydroxyl ions alkaline $\mathrm{pH}$ gradient damages cytoplasmic membrane proteins and alters membrane integrity. They act on diverse aspects, including organic components, nutrient transport, and the phospholipids or unsaturated fatty acids of cellular membranes. However, C. albicans survives at a wide range of $\mathrm{pH}$ values (3.0-8.0) and is resistant to calcium hydroxide [83], which has demonstrated little or no effect on intracanal fungal infections [84]. Extracellular $\mathrm{pH}$ controls C. albicans dimorphism, and thereby its pathogenicity. In alkaline $\mathrm{pH}, \mathrm{C}$. albicans adaptations involve filamentous growth, which is essential for pathogenicity [85]. Like other fungi, C. albicans mutants that lack $\mathrm{pH}$-response transcription factor PacC for $\mathrm{pH}$ regulation are defective in filamentous growth [86,87]. Additionally, C. albicans can utilize the $\mathrm{Ca}^{2+}$ released from calcium hydroxide as an essential for growth [84].

\section{Antimicrobial Peptides}

The intracanal application of antibiotics was common for endodontic treatment in the 1950s and 1960s. Most antibiotic pastes contained an antifungal component, usually nystatin or sodium caprylate. However, since the 1970s, intracanal antibiotics have been less frequently used due to risks of microbial resistance and host sensitization. Commonly used antibacterial irrigants and medications with limited antifungal effects may favor the overgrowth of yeasts within root canals [88]. Until recently, the importance of antifungal considerations in endodontic therapy received little attention.

Antimicrobial peptides (AMPs) that act through cell lysis could be promising as antifungal and antibiofilm intracanal medicaments. They are amphipathic and both neutral and positively charged molecules that bind and disrupt cellular membranes [89]. They traverse cellular membranes and interact with certain molecules or interfere with the cell wall or the synthesis of essential components, such as glucan and chitin [90]. These include defensins, which are mammalian peptides present in numerous organisms. The unique $\beta$-sheet structures of defensins stabilized by three disulfide bonds form highly amphipathic molecules with variably cationic charges. The three-dimensional folds enable reduced molecular size, whereas other antimicrobial peptides form helical structures. Their cationic properties make them electrostatically bond to membranes and form multimeric pores, which leak essential minerals and metabolites from microbial cells [91].

In endodontics, human beta defensin-3 (HBD3) was investigated for antibacterial and antifungal effects. Synthetic HBD3-C15 has fungicidal effects that may involve multifarious mechanisms. Like CHX, the antimicrobial action of HBD3 derivatives involves membrane permeabilization [69,92-98]. 
Their cationic amino acid residues and capacity to form dimers contribute to the depolarization and disruption of negatively charged microbial cell membrane lipopolysaccharides and lipoteichoic acid. HBD3 derivatives displace the $\mathrm{Ca}^{2+}$ or $\mathrm{Mg}^{2+}$ ions that normally bridge lipopolysaccharide molecules to form a pore complex on the membrane, and thereby depolarize and lyze bacterial cells (Figure 3) [98]. For enhanced clinical applications, these AMPs can be dissolved in various vehicles (aqueous, gel, etc.) and administered through an injectable syringe.
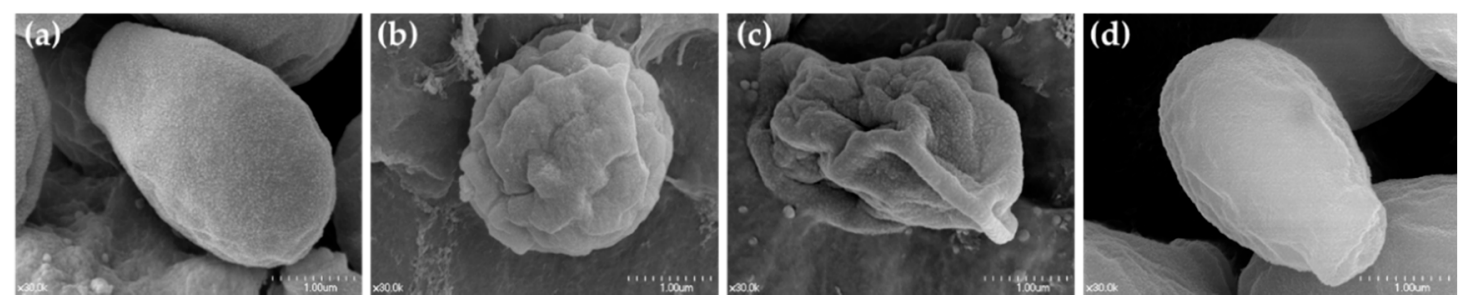

Figure 3. Scanning electron microscopic view of Candida albicans cell membranes disrupted by endodontic irrigants/medications (30,000×). (a) Saline (control), (b) chlorhexidine gel, (c) synthetic HBD3-C15, and (d) calcium hydroxide.

\section{Antifungal Agents}

Safe and effective antifungal agents are in increasing demand due to the expanding numbers of immunocompromised patients at risk of invasive fungal infections. However, the effects of antifungals, including nystatin and azole-based agents against intracanal fungal infections, are not well understood. This is largely due to deviating results from antimicrobial susceptibility tests to evaluate the antifungal capacity of agents or the resistance of strains. Waltimo et al. (100) reported differing susceptibilities to various antifungals for 70 strains of $C$. albicans isolated from cases of persistent apical periodontitis and of marginal periodontitis. They showed the limitations of in vitro studies for antifungal agents in endodontic applications. For example, propolis is a natural derivative that is well known for its antifungal activity against oral C. albicans infections [99], but little is known about its intracanal effects. Unlike oral manifestations, propolis antifungal effects in a C. albicans-infected human dentin disc model were reported to be significantly inferior than CHX [100,101].

\subsubsection{Root Canal Obturation}

Root canal obturations aim to obtain a 'fluid-tight seal' of the root canal system from periradicular tissues, which starves the remaining microorganisms and prevents re-infection. However, current obturation materials are limited by their setting properties, solubility, or cytotoxicity. Therefore, newer calcium-silicate (Ca-Si) materials that undergo setting within wet environments have gained attention for use in root canal obturation. Their hydration reactions create alkaline conditions that instill antibacterial properties [102,103], and most importantly, these materials induce intratubular biomineralization. Ca-Si-based hydroxyapatite precipitates were observed within dentinal tubules after root canals were filled, and these micromechanical biomineralized structures were considered as favorable retention $[104,105]$. Interestingly, further study reported dead microorganisms entrapped by these biomineralized precipitates within dentinal tubules [106]. Additionally, Ca-Si-based materials provide an opportunity for developing innovative root canal obturation materials, such as antimicrobial agents incorporated into Ca-Si-based sealers, or Ca-Si materials incorporated into gutta percha.

\subsection{Extraradicular Eradication}

Infected root canals may occasionally progress on through apical foramen to develop into extraradicular infections of the external root surface and periapical tissues. These could involve abscesses, apical actinomycosis, and osteomyelitis [23,24,107]. However, there are few reports on the presence of yeast in periapical tissues $[108,109]$. Case reports show that the extraradicular presence of 
yeast appears to be primarily associated with immunocompromised patients [110,111]. Such cases of suspected extraradicular infection that persist despite comprehensive root canal treatments may require additional microsurgical endodontics to heal.

\section{Conclusions}

C. albicans may survive and flourish despite endodontic treatment, due to their capacity to form biofilm, invade dentinal tubules, and resist commonly used intracanal disinfectants. Their pathogenicity involves dental pulp and periradicular tissue cells, especially in immunocompromised patients. Therefore, clinicians should consider the possibility of fungal infection when dealing with cases of secondary or refractory apical periodontitis. These may require additional treatments, including intracanal medicaments such as CHX gel or HBD3, root canal obturation with Ca-Si-based sealers, or microsurgeries. Future research needs to establish biocompatible disinfection strategies that provide the most effective antibacterial and antifungal treatment for endodontic infections.

Author Contributions: Conceptualization and methodology, K.-Y.K.; investigation, validation, data curation Y.-J.Y., A.R.K.; writing-original draft preparation, Y.-J.Y., A.R.K., and H.P.; writing-review and editing, K.-Y.K.; supervision, K.-Y.K. and S.H.H. All authors have read and agreed to the published version of the manuscript.

Funding: This work was supported by the Korea Health Technology R\&D Project through the Korea Health Industry Development Institute (KHIDI), funded by the Ministry of Health \& Welfare (HI17C1377), Republic of Korea.

Conflicts of Interest: The authors declare no conflict of interest.

\section{References}

1. Yu, C.; Abbott, P.V. An overview of the dental pulp: Its functions and responses to injury. Aust. Dent. J. 2007, 52, S4-S16. [CrossRef] [PubMed]

2. Siqueira, J.F., Jr.; Sen, B.H. Fungi in endodontic infections. Oral Surg. Oral Med. Oral Pathol. Oral Radiol. Endodontol. 2004, 97, 632-641. [CrossRef]

3. Mergoni, G.; Percudani, D.; Lodi, G.; Bertani, P.; Manfredi, M. Prevalence of Candida species in endodontic infections: Systematic review and meta-analysis. J. Endod. 2018, 44, 1616-1625.e1619. [CrossRef] [PubMed]

4. Douglas, L.J. Candida biofilms and their role in infection. Trends Microbiol. 2003, 11, 30-36. [CrossRef]

5. Gulati, M.; Nobile, C.J. Candida albicans biofilms: Development, regulation, and molecular mechanisms. Microbes Infect. 2016, 18, 310-321. [CrossRef]

6. Chandra, J.; Kuhn, D.M.; Mukherjee, P.K.; Hoyer, L.L.; McCormick, T.; Ghannoum, M.A. Biofilm formation by the fungal pathogen Candida albicans: Development, architecture, and drug resistance. J. Bacteriol. 2001, 183, 5385-5394. [CrossRef]

7. Sudbery, P.E. Growth of Candida albicans hyphae. Nat. Rev. Microbiol. 2011, 9, 737-748. [CrossRef]

8. Jacobsen, I.D.; Wilson, D.; Wachtler, B.; Brunke, S.; Naglik, J.R.; Hube, B. Candida albicans dimorphism as a therapeutic target. Expert Rev. Anti-Infect. 2012, 10, 85-93. [CrossRef]

9. Dalle, F.; Wachtler, B.; L'Ollivier, C.; Holland, G.; Bannert, N.; Wilson, D.; Labruere, C.; Bonnin, A.; Hube, B. Cellular interactions of Candida albicans with human oral epithelial cells and enterocytes. Cell. Microbiol. 2010, 12, 248-271. [CrossRef]

10. Drago, L.; Mombelli, B.; De Vecchi, E.; Bonaccorso, C.; Fassina, M.C.; Gismondo, M.R. Candida albicans cellular internalization: A new pathogenic factor? Int. J. Antimicrob. Agents 2000, 16, 545-547. [CrossRef]

11. Phan, Q.T.; Myers, C.L.; Fu, Y.; Sheppard, D.C.; Yeaman, M.R.; Welch, W.H.; Ibrahim, A.S.; Edwards, J.E., Jr.; Filler, S.G. Als3 is a Candida albicans invasin that binds to cadherins and induces endocytosis by host cells. PLoS Biol. 2007, 5, e64. [CrossRef] [PubMed]

12. Hoyer, L.L. The ALS gene family of Candida albicans. Trends Microbiol. 2001, 9, 176-180. [CrossRef]

13. Liu, Y.; Filler, S.G. Candida albicans Als3, a multifunctional adhesin and invasin. Eukaryot. Cell. 2011, 10, 168-173. [CrossRef] [PubMed]

14. Nobile, C.J.; Andes, D.R.; Nett, J.E.; Smith, F.J.; Yue, F.; Phan, Q.T.; Edwards, J.E.; Filler, S.G.; Mitchell, A.P. Critical role of Bcr1-dependent adhesins in C. albicans biofilm formation in vitro and in vivo. PLoS Pathog. 2006, 2, e63. [CrossRef] [PubMed] 
15. Sheth, C.C.; Hall, R.; Lewis, L.; Brown, A.J.; Odds, F.C.; Erwig, L.P.; Gow, N.A. Glycosylation status of the C. albicans cell wall affects the efficiency of neutrophil phagocytosis and killing but not cytokine signaling. Med. Mycol. 2011, 49, 513-524. [CrossRef]

16. Netea, M.G.; Brown, G.D.; Kullberg, B.J.; Gow, N.A. An integrated model of the recognition of Candida albicans by the innate immune system. Nat. Rev. Microbiol. 2008, 6, 67-78. [CrossRef]

17. Gantner, B.N.; Simmons, R.M.; Underhill, D.M. Dectin-1 mediates macrophage recognition of Candida albicans yeast but not filaments. EMBO J. 2005, 24, 1277-1286. [CrossRef]

18. Bates, S.; Hughes, H.B.; Munro, C.A.; Thomas, W.P.; MacCallum, D.M.; Bertram, G.; Atrih, A.; Ferguson, M.A.; Brown, A.J.; Odds, F.C.; et al. Outer chain N-glycans are required for cell wall integrity and virulence of Candida albicans. J. Biol. Chem. 2006, 281, 90-98. [CrossRef]

19. Chaffin, W.L.; Lopez-Ribot, J.L.; Casanova, M.; Gozalbo, D.; Martinez, J.P. Cell wall and secreted proteins of Candida albicans: Identification, function, and expression. Microbiol. Mol. Biol. Rev. 1998, 62, 130-180. [CrossRef]

20. Machova, E.; Fiacanova, L.; Cizova, A.; Korcova, J. Mannoproteins from yeast and hyphal form of Candida albicans considerably differ in mannan and protein content. Carbohydr. Res. 2015, 408, 12-17. [CrossRef]

21. Sakko, M.; Tjaderhane, L.; Rautemaa-Richardson, R. Microbiology of Root Canal Infections. Prim. Dent. J. 2016, 5, 84-89. [CrossRef] [PubMed]

22. Silva, T.A.; Garlet, G.P.; Fukada, S.Y.; Silva, J.S.; Cunha, F.Q. Chemokines in oral inflammatory diseases: Apical periodontitis and periodontal disease. J. Dent. Res. 2007, 86, 306-319. [CrossRef] [PubMed]

23. Nair, P.N. Pathogenesis of apical periodontitis and the causes of endodontic failures. Crit. Rev. Oral Biol. Med. 2004, 15, 348-381. [CrossRef] [PubMed]

24. Nair, P.N. Apical periodontitis: A dynamic encounter between root canal infection and host response. Periodontol. 2000 1997, 13, 121-148. [CrossRef]

25. Rodini, C.O.; Lara, V.S. Study of the expression of CD68+ macrophages and CD8+ T cells in human granulomas and periapical cysts. Oral Surg. Oral Med. Oral Pathol. Oral Radiol. Endodontol. 2001, 92, 221-227. [CrossRef] [PubMed]

26. de Oliveira Rodini, C.; Batista, A.C.; Lara, V.S. Comparative immunohistochemical study of the presence of mast cells in apical granulomas and periapical cysts: Possible role of mast cells in the course of human periapical lesions. Oral Surg. Oral Med. Oral Pathol. Oral Radiol. Endodontol. 2004, 97, 59-63. [CrossRef]

27. Tong, Y.; Tang, J. Candida albicans infection and intestinal immunity. Microbiol. Res. 2017, 198, 27-35. [CrossRef]

28. Jouault, T.; Ibata-Ombetta, S.; Takeuchi, O.; Trinel, P.A.; Sacchetti, P.; Lefebvre, P.; Akira, S.; Poulain, D. Candida albicans phospholipomannan is sensed through toll-like receptors. J. Infect. Dis. 2003, 188, 165-172. [CrossRef]

29. Netea, M.G.; Gow, N.A.; Munro, C.A.; Bates, S.; Collins, C.; Ferwerda, G.; Hobson, R.P.; Bertram, G.; Hughes, H.B.; Jansen, T.; et al. Immune sensing of Candida albicans requires cooperative recognition of mannans and glucans by lectin and Toll-like receptors. J. Clin. Investig. 2006, 116, 1642-1650. [CrossRef]

30. van de Veerdonk, F.L.; Marijnissen, R.J.; Kullberg, B.J.; Koenen, H.J.; Cheng, S.C.; Joosten, I.; van den Berg, W.B.; Williams, D.L.; van der Meer, J.W.; Joosten, L.A.; et al. The macrophage mannose receptor induces IL-17 in response to Candida albicans. Cell Host Microbe 2009, 5, 329-340. [CrossRef]

31. Wells, C.A.; Salvage-Jones, J.A.; Li, X.; Hitchens, K.; Butcher, S.; Murray, R.Z.; Beckhouse, A.G.; Lo, Y.L.; Manzanero, S.; Cobbold, C.; et al. The macrophage-inducible C-type lectin, mincle, is an essential component of the innate immune response to Candida albicans. J. Immunol. 2008, 180, 7404-7413. [CrossRef] [PubMed]

32. Wang, M.; Wang, F.; Yang, J.; Zhao, D.; Wang, H.; Shao, F.; Wang, W.; Sun, R.; Ling, M.; Zhai, J.; et al. Mannan-binding lectin inhibits Candida albicans-induced cellular responses in PMA-activated THP-1 cells through Toll-like receptor 2 and Toll-like receptor 4. PLoS ONE 2013, 8, e83517. [CrossRef] [PubMed]

33. Thompson, A.; Davies, L.C.; Liao, C.T.; da Fonseca, D.M.; Griffiths, J.S.; Andrews, R.; Jones, A.V.; Clement, M.; Brown, G.D.; Humphreys, I.R.; et al. The protective effect of inflammatory monocytes during systemic C. albicans infection is dependent on collaboration between C-type lectin-like receptors. PLoS Pathog. 2019, 15, e1007850. [CrossRef] [PubMed]

34. Wellington, M.; Koselny, K.; Sutterwala, F.S.; Krysan, D.J. Candida albicans triggers NLRP3-mediated pyroptosis in macrophages. Eukaryot. Cell 2014, 13, 329-340. [CrossRef] [PubMed] 
35. Joly, S.; Ma, N.; Sadler, J.J.; Soll, D.R.; Cassel, S.L.; Sutterwala, F.S. Cutting edge: Candida albicans hyphae formation triggers activation of the Nlrp3 inflammasome. J. Immunol. 2009, 183, 3578-3581. [CrossRef] [PubMed]

36. Rogiers, O.; Frising, U.C.; Kucharikova, S.; Jabra-Rizk, M.A.; van Loo, G.; Van Dijck, P.; Wullaert, A. Candidalysin crucially contributes to Nlrp3 inflammasome activation by Candida albicans hyphae. mBio 2019, 10. [CrossRef]

37. Kasper, L.; Konig, A.; Koenig, P.A.; Gresnigt, M.S.; Westman, J.; Drummond, R.A.; Lionakis, M.S.; Gross, O.; Ruland, J.; Naglik, J.R.; et al. The fungal peptide toxin Candidalysin activates the NLRP3 inflammasome and causes cytolysis in mononuclear phagocytes. Nat. Commun. 2018, 9, 4260. [CrossRef]

38. Pietrella, D.; Pandey, N.; Gabrielli, E.; Pericolini, E.; Perito, S.; Kasper, L.; Bistoni, F.; Cassone, A.; Hube, B.; Vecchiarelli, A. Secreted aspartic proteases of Candida albicans activate the NLRP3 inflammasome. Eur. J. Immunol. 2013, 43, 679-692. [CrossRef]

39. Ganesan, S.; Rathinam, V.A.K.; Bossaller, L.; Army, K.; Kaiser, W.J.; Mocarski, E.S.; Dillon, C.P.; Green, D.R.; Mayadas, T.N.; Levitz, S.M.; et al. Caspase-8 modulates dectin-1 and complement receptor 3-driven IL-1beta production in response to beta-glucans and the fungal pathogen, Candida albicans. J. Immunol. 2014, 193, 2519-2530. [CrossRef]

40. Joly, S.; Eisenbarth, S.C.; Olivier, A.K.; Williams, A.; Kaplan, D.H.; Cassel, S.L.; Flavell, R.A.; Sutterwala, F.S. Cutting edge: Nlrp10 is essential for protective antifungal adaptive immunity against Candida albicans. J. Immunol. 2012, 189, 4713-4717. [CrossRef]

41. Wagener, J.; MacCallum, D.M.; Brown, G.D.; Gow, N.A. Candida albicans chitin increases arginase-1 activity in human macrophages, with an Impact on macrophage antimicrobial functions. mBio 2017, 8. [CrossRef] [PubMed]

42. d'Ostiani, C.F.; Del Sero, G.; Bacci, A.; Montagnoli, C.; Spreca, A.; Mencacci, A.; Ricciardi-Castagnoli, P.; Romani, L. Dendritic cells discriminate between yeasts and hyphae of the fungus Candida albicans. Implications for initiation of T helper cell immunity in vitro and in vivo. J. Exp. Med. 2000, 191, 1661-1674. [CrossRef]

43. Munoz-Duarte, A.R.; Castrejon-Jimenez, N.S.; Baltierra-Uribe, S.L.; Perez-Rangel, S.J.; Carapia-Minero, N.; Castaneda-Sanchez, J.I.; Luna-Herrera, J.; Lopez-Santiago, R.; Rodriguez-Tovar, A.V.; Garcia-Perez, B.E. Candida glabrata survives and replicates in human osteoblasts. Pathog. Dis. 2016, 74, ftw030. [CrossRef]

44. Romani, L.; Bistoni, F.; Puccetti, P. Fungi, dendritic cells and receptors: A host perspective of fungal virulence. Trends Microbiol. 2002, 10, 508-514. [CrossRef]

45. De Zuani, M.; Paolicelli, G.; Zelante, T.; Renga, G.; Romani, L.; Arzese, A.; Pucillo, C.E.M.; Frossi, B. Mast cells respond to Candida albicans infections and modulate macrophages phagocytosis of the fungus. Front. Immunol. 2018, 9, 2829. [CrossRef] [PubMed]

46. Verma, A.H.; Richardson, J.P.; Zhou, C.; Coleman, B.M.; Moyes, D.L.; Ho, J.; Huppler, A.R.; Ramani, K.; McGeachy, M.J.; Mufazalov, I.A.; et al. Oral epithelial cells orchestrate innate type 17 responses to Candida albicans through the virulence factor candidalysin. Sci. Immunol. 2017, 2, eaam8834. [CrossRef] [PubMed]

47. Swidergall, M.; Solis, N.V.; Lionakis, M.S.; Filler, S.G. EphA2 is an epithelial cell pattern recognition receptor for fungal beta-glucans. Nat. Microbiol. 2018, 3, 53-61. [CrossRef]

48. Ishida, Y.; Ohta, K.; Naruse, T.; Kato, H.; Fukui, A.; Shigeishi, H.; Nishi, H.; Tobiume, K.; Takechi, M. Candida albicans beta-glucan-containing particles increase HO-1 expression in oral keratinocytes via a reactive oxygen species/p38 mitogen-activated protein kinase/Nrf2 pathway. Infect. Immunol. 2018, 86, e00575-e00617. [CrossRef]

49. Taille, C.; El-Benna, J.; Lanone, S.; Dang, M.C.; Ogier-Denis, E.; Aubier, M.; Boczkowski, J. Induction of heme oxygenase- 1 inhibits $\mathrm{NAD}(\mathrm{P}) \mathrm{H}$ oxidase activity by down-regulating cytochrome b558 expression via the reduction of heme availability. J. Biol. Chem. 2004, 279, 28681-28688. [CrossRef]

50. Gao, Y.; Liang, G.; Wang, Q.; She, X.; Shi, D.; Shen, Y.; Su, X.; Wang, X.; Wang, W.; Li, D.; et al. Different host immunological response to C. albicans by human oral and vaginal epithelial cells. Mycopathologia 2019, 184, 1-12. [CrossRef]

51. Tamai, R.; Kiyoura, Y. Candida albicans and Candida parapsilosis rapidly up-regulate galectin-3 secretion by human gingival epithelial cells. Mycopathologia 2014, 177, 75-79. [CrossRef] [PubMed]

52. Villar, C.C.; Zhao, X.R. Candida albicans induces early apoptosis followed by secondary necrosis in oral epithelial cells. Mol. Oral Microbiol. 2010, 25, 215-225. [CrossRef] [PubMed] 
53. Dongari-Bagtzoglou, A.; Villar, C.C.; Kashleva, H. Candida albicans-infected oral epithelial cells augment the anti-fungal activity of human neutrophils in vitro. Med. Mycol. 2005, 43, 545-549. [CrossRef]

54. Ohta, K.; Nishi, H.; Fukui, A.; Shigeishi, H.; Takechi, M.; Kamata, N. CX3CL1 expression induced by Candida albicans in oral fibroblasts. FEMS Immunol. Med. Microbiol. 2010, 60, 179-185. [CrossRef]

55. Alsalleeh, F.; Young, A.; Algarawi, Z.; Petro, T. C. Albicans biofilm formation is restricted by periodontal ligament cells and induces differential cytokines response compared to planktonic C. Albicans. J. Dent. Appl. 2014, 1, 139-144.

56. Yu, Q.; Li, J.; Zhang, Y.; Wang, Y.; Liu, L.; Li, M. Inhibition of gold nanoparticles (AuNPs) on pathogenic biofilm formation and invasion to host cells. Sci. Rep. 2016, 6, 26667. [CrossRef] [PubMed]

57. Angata, T. Siglec-15: A potential regulator of osteoporosis, cancer, and infectious diseases. J. Biomed. Sci. 2020, 27, 10. [CrossRef] [PubMed]

58. Maher, C.O.; Dunne, K.; Comerford, R.; O’Dea, S.; Loy, A.; Woo, J.; Rogers, T.R.; Mulcahy, F.; Dunne, P.J.; Doherty, D.G. Candida albicans stimulates IL-23 release by human dendritic cells and downstream IL-17 secretion by Vdelta1 T cells. J. Immunol. 2015, 194, 5953-5960. [CrossRef]

59. Nur, S.; Sparber, F.; Lemberg, C.; Guiducci, E.; Schweizer, T.A.; Zwicky, P.; Becher, B.; LeibundGut-Landmann, S. IL-23 supports host defense against systemic Candida albicans infection by ensuring myeloid cell survival. PLoS Pathog. 2019, 15, e1008115. [CrossRef]

60. Zhu, X.; Zhao, Y.; Jiang, Y.; Qin, T.; Chen, J.; Chu, X.; Yi, Q.; Gao, S.; Wang, S. Dectin-1 signaling inhibits osteoclastogenesis via IL-33-induced inhibition of NFATc1. Oncotarget 2017, 8, 53366-53374. [CrossRef]

61. Maruyama, K.; Takayama, Y.; Kondo, T.; Ishibashi, K.I.; Sahoo, B.R.; Kanemaru, H.; Kumagai, Y.; Martino, M.M.; Tanaka, H.; Ohno, N.; et al. Nociceptors boost the resolution of fungal osteoinflammation via the TRP channel-CGRP-Jdp2 axis. Cell Rep. 2017, 19, 2730-2742. [CrossRef] [PubMed]

62. Amanai, T.; Nakamura, Y.; Aoki, S.; Mataga, I. Micro-CT analysis of experimental Candida osteoarthritis in rats. Mycopathologia 2008, 166, 133-141. [CrossRef] [PubMed]

63. Nakamura, Y.; Noda, S.; Masuhara, T.; Ito-Kuwa, S.; Nakamura, K.; Aoki, S. Radiographic features of experimental Candida arthritis in rats. Mycopathologia 1993, 121, 65-75. [CrossRef] [PubMed]

64. Doughty-Shenton, D.; Joseph, J.D.; Zhang, J.; Pagliarini, D.J.; Kim, Y.; Lu, D.; Dixon, J.E.; Casey, P.J. Pharmacological targeting of the mitochondrial phosphatase PTPMT1. J. Pharm. Exp. 2010, 333, 584-592. [CrossRef] [PubMed]

65. Arnhold, J.; Wiegel, D.; Richter, O.; Hammerschmidt, S.; Arnold, K.; Krumbiegel, M. Modification of low density lipoproteins by sodium hypochlorite. Biomed. Biochim. Acta 1991, 50, 967-973. [PubMed]

66. Webb, B.C.; Willcox, M.D.; Thomas, C.J.; Harty, D.W.; Knox, K.W. The effect of sodium hypochlorite on potential pathogenic traits of Candida albicans and other Candida species. Oral Microbiol. Immunol. 1995, 10, 334-341. [CrossRef]

67. Parsons, G.J.; Patterson, S.S.; Miller, C.H.; Katz, S.; Kafrawy, A.H.; Newton, C.W. Uptake and release of chlorhexidine by bovine pulp and dentin specimens and their subsequent acquisition of anti-bacterial properties. Oral Surg. Oral Med. Oral Pathol. 1980, 49, 455-459. [CrossRef]

68. Bobichon, H.; Bouchet, P. Action of chlorhexidine on budding Candida albicans: Scanning and transmission electron microscopic study. Mycopathologia 1987, 100, 27-35. [CrossRef]

69. Yoo, Y.J.; Kwon, I.; Oh, S.R.; Perinpanayagam, H.; Lim, S.M.; Ahn, K.B.; Lee, Y.; Han, S.H.; Chang, S.W.; Baek, S.H.; et al. Antifungal effects of synthetic human beta-defensin-3-C15 peptide on Candida albicans-infected root dentin. J. Endod. 2017, 43, 1857-1861. [CrossRef]

70. Krithikadatta, J.; Indira, R.; Dorothykalyani, A.L. Disinfection of dentinal tubules with $2 \%$ chlorhexidine, $2 \%$ metronidazole, bioactive glass when compared with calcium hydroxide as intracanal medicaments. J. Endod. 2007, 33, 1473-1476. [CrossRef]

71. Ercan, E.; Dalli, M.; Dulgergil, C.T. In vitro assessment of the effectiveness of chlorhexidine gel and calcium hydroxide paste with chlorhexidine against Enterococcus faecalis and Candida albicans. Oral Surg. Oral Med. Oral Pathol. Oral Radiol. Endodontol. 2006, 102, e27-e31. [CrossRef] [PubMed]

72. Mohammadi, Z.; Abbott, P.V. The properties and applications of chlorhexidine in endodontics. Int. Endod. J. 2009, 42, 288-302. [CrossRef] [PubMed]

73. Okino, L.A.; Siqueira, E.L.; Santos, M.; Bombana, A.C.; Figueiredo, J.A. Dissolution of pulp tissue by aqueous solution of chlorhexidine digluconate and chlorhexidine digluconate gel. Int. Endod. J. 2004, 37, 38-41. [CrossRef] [PubMed] 
74. Mamouei, Z.; Alqarihi, A.; Singh, S.; Xu, S.Y.; Mansour, M.K.; Ibrahim, A.S.; Uppuluri, P. Alexidine dihydrochloride has broad-spectrum activities against diverse fungal pathogens. mSphere 2018, 3, e00539-e00618. [CrossRef]

75. Barrios, R.; Ferrer-Luque, C.M.; Arias-Moliz, M.T.; Ruiz-Linares, M.; Bravo, M.; Baca, P. Antimicrobial substantivity of alexidine and chlorhexidine in dentin. J. Endod. 2013, 39, 1413-1415. [CrossRef]

76. Kim, H.S.; Zhu, Q.; Baek, S.H.; Jung, I.Y.; Son, W.J.; Chang, S.W.; Lee, W.; Gu, Y.; Lee, Y.; Hong, S.T.; et al. Chemical interaction of alexidine and sodium hypochlorite. J. Endod. 2012, 38, 112-116. [CrossRef]

77. Orstavik, D.; Haapasalo, M. Disinfection by endodontic irrigants and dressings of experimentally infected dentinal tubules. Endod. Dent. Traumatol. 1990, 6, 142-149. [CrossRef]

78. Sen, B.H.; Akdeniz, B.G.; Denizci, A.A. The effect of ethylenediamine-tetraacetic acid on Candida albicans. Oral Surg. Oral Med. Oral Pathol. 2000, 90, 651-655. [CrossRef]

79. Pugh, D.; Cawson, R.A. Calcium, sequestering agents and nystatin-interactions on cell wall morphology and fungistasis of Candida albicans. Sabouraudia 1980, 18, 157-159. [CrossRef]

80. Bedell, G.W.; Soll, D.R. Effects of low concentrations of zinc on the growth and dimorphism of Candida albicans: Evidence for zinc-resistant and -sensitive pathways for mycelium formation. Infect. Immunol. 1979, 26, 348-354. [CrossRef]

81. Holmes, A.R.; Cannon, R.D.; Shepherd, M.G. Effect of calcium ion uptake on Candida albicans morphology. FEMS Microbiol. Lett. 1991, 61, 187-193. [CrossRef] [PubMed]

82. Sohnle, P.G.; Hahn, B.L.; Karmarkar, R. Effect of metals on Candida albicans growth in the presence of chemical chelators and human abscess fluid. J. Lab. Clin. Med. 2001, 137, 284-289. [CrossRef] [PubMed]

83. Johnson, S.A.M. Candida (Monilia) Albicans-Effect of amino acids, glucose, $\mathrm{pH}$, chlortetracycline (aureomycin), dibasic sodium and calcium phosphates, and anaerobic and aerobic conditions on Its growth. AMA Arch. Derm. Syph. 1954, 70, 49-60. [CrossRef] [PubMed]

84. Waltimo, T.M.; Siren, E.K.; Orstavik, D.; Haapasalo, M.P. Susceptibility of oral Candida species to calcium hydroxide in vitro. Int. Endod. J. 1999, 32, 94-98. [CrossRef]

85. Denison, S.H. pH regulation of gene expression in fungi. Fungal Genet. Biol. 2000, 29, 61-71. [CrossRef]

86. Ramon, A.M.; Porta, A.; Fonzi, W.A. Effect of environmental pH on morphological development of Candida albicans is mediated via the PacC-related transcription factor encoded by PRR2. J. Bacteriol. 1999, 181, 7524-7530. [CrossRef]

87. Wilson, R.B.; Davis, D.; Mitchell, A.P. Rapid hypothesis testing with Candida albicans through gene disruption with short homology regions. J. Bacteriol. 1999, 181, 1868-1874. [CrossRef]

88. Sen, B.H.; Safavi, K.E.; Spangberg, L.S. Antifungal effects of sodium hypochlorite and chlorhexidine in root canals. J. Endod. 1999, 25, 235-238. [CrossRef]

89. Shai, Y. Molecular recognition between membrane-spanning polypeptides. Trends Biochem. Sci. 1995, 20, 460-464. [CrossRef]

90. Debono, M.; Gordee, R.S. Antibiotics that inhibit fungal cell-wall development. Annu. Rev. Microbiol. 1994, 48, 471-497. [CrossRef]

91. White, S.H.; Wimley, W.C.; Selsted, M.E. Structure, function, and membrane integration of defensins. Curr. Opin. Struct. Biol. 1995, 5, 521-527. [CrossRef]

92. Schneider, J.J.; Unholzer, A.; Schaller, M.; Schafer-Korting, M.; Korting, H.C. Human defensins. J. Mol. Med. 2005, 83, 587-595. [CrossRef] [PubMed]

93. Hoover, D.M.; Wu, Z.; Tucker, K.; Lu, W.; Lubkowski, J. Antimicrobial characterization of human beta-defensin 3 derivatives. Antimicrob. Agents Chemother. 2003, 47, 2804-2809. [CrossRef] [PubMed]

94. Krishnakumari, V.; Rangaraj, N.; Nagaraj, R. Antifungal activities of human beta-defensins HBD-1 to HBD-3 and their C-terminal analogs Phd1 to Phd3. Antimicrob Agents Chemother. 2009, 53, 256-260. [CrossRef] [PubMed]

95. Lim, S.M.; Ahn, K.B.; Kim, C.; Kum, J.W.; Perinpanayagam, H.; Gu, Y.; Yoo, Y.J.; Chang, S.W.; Han, S.H.; Shon, W.J.; et al. Antifungal effects of synthetic human beta-defensin 3-C15 peptide. Restor. Dent. Endod. 2016, 41, 91-97. [CrossRef] [PubMed]

96. Feng, Z.; Jiang, B.; Chandra, J.; Ghannoum, M.; Nelson, S.; Weinberg, A. Human beta-defensins: Differential activity against candidal species and regulation by Candida albicans. J. Dent. Res. 2005, 84, 445-450. [CrossRef] 
97. Lee, J.Y.; Suh, J.S.; Kim, J.M.; Kim, J.H.; Park, H.J.; Park, Y.J.; Chung, C.P. Identification of a cell-penetrating peptide domain from human beta-defensin 3 and characterization of its anti-inflammatory activity. Int. J. Nanomed. 2015, 10, 5423-5434. [CrossRef]

98. Hancock, R.E. Peptide antibiotics. Lancet 1997, 349, 418-422. [CrossRef]

99. Ota, C.; Unterkircher, C.; Fantinato, V.; Shimizu, M.T. Antifungal activity of propolis on different species of Candida. Mycoses 2001, 44, 375-378. [CrossRef]

100. Chua, E.G.; Parolia, A.; Ahlawat, P.; Pau, A.; Amalraj, F.D. Antifungal effectiveness of various intracanal medicaments against Candida albicans: An ex-vivo study. BMC Oral Health 2014, 14, 53. [CrossRef]

101. Carbajal Mejia, J.B. Antimicrobial effects of calcium hydroxide, chlorhexidine, and propolis on Enterococcus faecalis and Candida albicans. J. Investig. Clin. Dent. 2014, 5, 194-200. [CrossRef] [PubMed]

102. McHugh, C.P.; Zhang, P.; Michalek, S.; Eleazer, P.D. pH required to kill Enterococcus faecalis in vitro. J. Endod. 2004, 30, 218-219. [CrossRef] [PubMed]

103. Al-Hezaimi, K.; Al-Hamdan, K.; Naghshbandi, J.; Oglesby, S.; Simon, J.H.S.; Rotstein, I. Effect of white-colored mineral trioxide aggregate in different concentrations on Candida albicans in vitro. J. Endod. 2005, 31, 684-686. [CrossRef] [PubMed]

104. Adl, A.; Sadat Shojaee, N.; Pourhatami, N. Evaluation of the dislodgement resistance of a new Pozzolan-based cement (EndoSeal MTA) compared to ProRoot MTA and Biodentine in the presence and absence of blood. Scanning 2019, 2019, 3863069. [CrossRef] [PubMed]

105. Reyes-Carmona, J.F.; Felippe, M.S.; Felippe, W.T. The biomineralization ability of mineral trioxide aggregate and Portland cement on dentin enhances the push-out strength. J. Endod. 2010, 36, 286-291. [CrossRef] [PubMed]

106. Yoo, J.S.; Chang, S.W.; Oh, S.R.; Perinpanayagam, H.; Lim, S.M.; Yoo, Y.J.; Oh, Y.R.; Woo, S.B.; Han, S.H.; Zhu, Q.; et al. Bacterial entombment by intratubular mineralization following orthograde mineral trioxide aggregate obturation: A scanning electron microscopy study. Int. J. Oral Sci. 2014, 6, 227-232. [CrossRef]

107. Nair, P.N. On the causes of persistent apical periodontitis: A review. Int. Endod. J. 2006, 39, $249-281$. [CrossRef]

108. Nair, P.N.; Sjogren, U.; Krey, G.; Kahnberg, K.E.; Sundqvist, G. Intraradicular bacteria and fungi in root-filled, asymptomatic human teeth with therapy-resistant periapical lesions: A long-term light and electron microscopic follow-up study. J. Endod. 1990, 16, 580-588. [CrossRef]

109. Lomcali, G.; Sen, B.H.; Cankaya, H. Scanning electron microscopic observations of apical root surfaces of teeth with apical periodontitis. Endod. Dent. Traumatol. 1996, 12, 70-76. [CrossRef]

110. Damm, D.D.; Neville, B.W.; Geissler, R.H., Jr.; White, D.K.; Drummond, J.F.; Ferretti, G.A. Dentinal candidiasis in cancer patients. Oral Surg. Oral Med. Oral Pathol. 1988, 65, 56-60. [CrossRef]

111. Eidelman, D.; Neuman, I.; Kuttin, E.S.; Pinto, M.; Beemer, A.M. Dental sepsis due to Candida albicans causing urticaria-case report. Ann. Allergy 1978, 41, 179-181. [PubMed] 